\title{
ОЦІНКА ЯКОСТІ НАДАННЯ МЕДИЧНИХ ПОСЛУГ СЕРЕДНІМ МЕДИЧНИМ ПЕРСОНАЛОМ В УМОВАХ ПРИВАТНОГО МЕДИЧНОГО ЦЕНТРУ
}

\author{
М. Д. Дерлюк, Н. І. Рега \\ ТОВ «Центр хірургії ока професора Загурського» М. Луцьк \\ ДВНЗ «Тернопільський державний медичний університет \\ імені І. Я. Горбачевського МОЗ Украӥни»
}

\begin{abstract}
У статті проведено аналіз літератури з даної проблеми та класифіковано показники якості роботи середнього медичного персоналу. Проведено аналіз якості роботи медичних сестер приватного медичного офтальмологічного центру ТОВ «Центр хірургії ока професора Загурського» за 2015 р. та запропоновано шляхи вдосконалення та оптимізації роботи медичного персоналу для досягнення кращих результатів лікування та задоволеності пацієнтів.
\end{abstract}

\section{QUALITY ASSESSMENT OF HELTH SERVICES PROVISION BY NURSING STAFF UNDER PRIVATE MEDICAL CENTER}

\author{
M. D. Derlyuk, N. I. Reha \\ Ophthalmic Clinic «Professor Zahurskyi Eye Surgery Center», Lutsk \\ I. Horbachevsky Ternopil State Medical University
}

The article analyzes the literature and classifies the quality of the nursing staff, according to which the analysis of the quality of the nurses of Private Medical Ophthalmologic Center «Professor Zahurskyi Eye Surgery Center» for 2015 and suggests the ways to improve the optimization of the medical staff to achieve better treatment outcomes and satisfaction of patients.

Вступ. В Україні сьогодні триває державно-правова реформа, цей процес охоплює і медичне законодавство. Держава сприяє розвитку лікувальних закладів усіх форм власності. 3 огляду на це вивчення проблем і засад профілактичної, лікувальної медицини, організаційно-інформаційного та матеріально-технічного забезпечення системи охорони здоров'я $\epsilon$ нагальною проблемою сьогодення [1].

Сучасне трактування ВООЗ сестринської справи містить в собі не лише визначення ії місця і завдань в системі охорони здоров'я, а й чітко окреслює коло функціональних обов'язків медичної сестри: «Сестринська справа - це складова частина системи охорони здоров'я, яка направлена на вирішення проблем індивідуального та громадського здоров'я населення в мінливих умовах навколишнього середовища» [2].

Зростання ролі медсестринської служби в сучасній медицині змушує змінювати підготовку кадрів, розглядати медсестру як фахівця, яка найперше контактує з

(с М. Д. Дерлюк, Н. І. Рега, 2016 пацієнтом та його оточенням, та є основним помічником лікаря. У більшості європейських країн запроваджена багаторівнева вища освіта для медсестринської служби, що дозволяє медсестрам працювати на керівних посадах, бути менеджерами медичних установ, виконувати надскладні завдання [3].

Якість сестринського обслуговування $є$ одним із найважливіших аспектів якості медичної допомоги населенню в цілому [4]. Розвиток системи сестринського обслуговування $є$ частиною загальної тенденції до подальшого підвищення економічної ефективності системи охорони здоров'я. Якісною медичною послугою вважається та, яка відповідає досягненням сучасної науки та передової практики, позитивно впливає на здоров'я пацієнта та задовольняє його потреби.

Європейське бюро ВООЗ у звіті, присвяченому формуванню принципів забезпечення якості медичної допомоги, вказало на необхідність при вирішенні даної проблеми враховувати чотири елементи [5]:

1. Кваліфікацію спеціаліста. 
2. Оптимальність використання ресурсів.

3. Ризик для пацієнта.

4. Задоволеність пацієнта від взаємодії з медичною підсистемою.

Якість медичної допомоги - це властивість процесу взаємодії лікаря та пацієнта, зумовлена кваліфікацією персоналу, тобто спроможністю медперсоналу знижувати ризик прогресування захворювання та появи нового патологічного процесу, оптимально використовувати ресурси медицини та забезпечувати задоволеність пацієнта від його взаємодії з медичною системою [3].

У процесі реформування системи охорони здоров'я розглядається роль середньої медичної ланки в сторону збільшення їі самостійності. Однак сформовані традиційні підходи до ролі медичних сестеру лікувальнодіагностичному процесі державних медичних установ поки гальмують їх розвиток та самовдосконалення для виконання більш складних та відповідальних видів діяльності [6]. Слід чітко уявляти, що в кінцевому результаті роботи лікаря закладена чимала частка результату діяльності сестринського персоналу. Якщо якість роботи лікаря в більшості випадків оцінюється за кінцевим результатом, то виділити в цьому результаті частку середнього медперсоналу і оцінити, наскільки якість роботи медичної сестри вплинула на стан здоров'я хворого, нерідко досить складно, особливо, якщо відсутні прямі докази такого впливу.

Це $є$ особливо актуальним у світлі того, що відбувається реформування сестринської практики, ії стандартизація і документування сестринського процесу. Поняття якості сестринської допомоги нерозривно пов'язане з лікувально-діагностичним процесом, тому сестринському персоналу, від якого значною мірою залежить ефективність діагностики, лікування, реабілітації, одужання пацієнта, в цьому процесі відведена значна роль [7].

Основна частина. В багатьох країнах Європи (Польща, Чехія, Німеччина та ін.) середній медичний персонал має приблизно половину повноважень, які на сьогодні виконує лікару державних медичних установах України. За таким же принципом побудована і діяльність ТОВ «Центр хірургії ока професора Загурського» (ТОВ «ЦХО»), що працює в м. Луцьку та є частиною мережі клінік Польщі. 32009 р. медичний персонал ТОВ «ЦХО» виконує свою роботу відповідно до міжнародних стандартів та розроблених алгоритмів для кожного працівника на всіх ланках надання медичних послуг. Це підтверджують сертифікати якості ISO2009, «Чиста лікарня безпечна для пацієнта» (2013,
2014, 2015), нагороди Волинської облдержадміністрації, Луцької міської ради, Волинського відділення УТОС, Всеукраїнського товариства офтальмологів та ін., а також постійно зростаюча кількість задоволених пацієнтів, яким вдалось отримати якісні медичні послуги та повернути зір.

У ході дослідження було опрацьовано медичну документацію приватного медичного центру ТОВ «Центр хірургії ока професора Загурського», а саме понад 10000 медичних карток пацієнтів, які лікувалися протягом 2015 р., стандарти надання медичних послуг у клініці, адаптовані для надання допомоги в Україні, але основані на міжнародних стандартах медичної офтальмологічної допомоги, журнали прийому пацієнтів, санітарно-гігієнічного контролю, алгоритми роботи працівників ТОВ «ЦХО».

Виділено основні критерії, за якими потрібно оцінювати роботу медичних сестер [2, 3]:

- правильність виконання процедур;

- своєчасність виконання лікарських призначень;

- дотримання санітарних норм;

- ведення документації;

- порядок у відділенні в цілому;

- оцінка дотримання медичними сестрами етичних норм;

- задоволеність (позитивна оцінка) пацієнтів від роботи медичних сестер.

Експертна оцінка роботи медичного персоналу $\epsilon$ надзвичайно важливим елементом у характеристиці якості медичної допомоги. Вона передбачає визначення відповідності конкретних результатів діагностики, лікування, профілактики захворювань та реабілітації хворих так званим стандартам якості. Одним із об'єктів експертної оцінки є аналіз медичної документації [6]. У ТОВ «Центр хірургії ока професора Загурського» використовується така медична документація, яку заповнює медична сестра:

- медична карта амбулаторного хворого (в електронному та паперовому вигляді);

- операційний журнал;

- журнал проведення лазерних процедур;

- журнал обігу медикаментів;

- журнал забору матеріалу для лабораторних обстежень.

Метою дослідження була оцінка роботи середнього медичного персоналу на основі думки всіх учасників лікувально-діагностичного процесу та аналіз документації, яка використовується в роботі та контролі діяльності медперсоналу клініки ТОВ «ЦХО». 
Здійснено анкетування пацієнтів, оцінено кількість позитивних і негативних відгуків у цілому із надання послуг в клініці та конкретно із роботи окремих ланок персоналу: реєстратор, медсестра, лікар. У штаті ТОВ «ЦХО» працює 8 медсестер діагностичного відділення, які працюють позмінно. При аналізі анкет пацієнтів встановлено, що 75 \% хворих задоволені роботою медичного персоналу в цілому, 3 \% незадоволені та 15 \% пацієнтів байдуже; 7 \% опитаних не визначились з відгуком після першого візиту до клініки, оскільки не змогли відразу оцінити результат лікування.

Дані анкетування проілюстровано на рисунку 1.

\section{Анкетування пацієнтів, які пройшли обстеження}

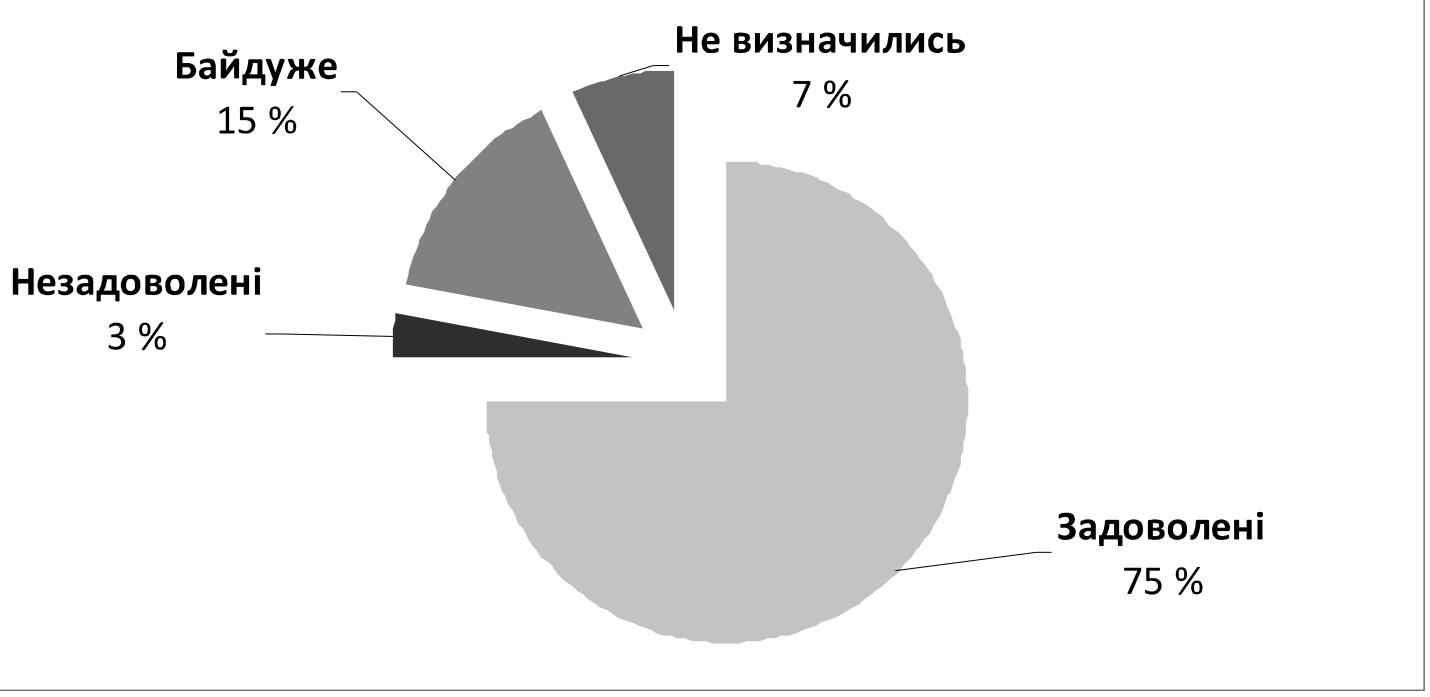

Puc. 1. Результати анкетування пацієнтів ТОВ «ЦХО» при оцінці якості роботи медперсоналу в цілому.

Результати анкетування пацієнтів ТОВ «ЦХО» стосовно діяльності кожного конкретного працівника серед середнього медичного персоналу подано у таблиці 1. Кожній медсестрі присвоєно порядковий номер, про який повідомляли пацієнтові перед анкетуванням. Проводили дослідження у діагностичному відділенні ТОВ «ЦХО» вибірковим методом, двома шляхами: опитуванням пацієнта (анкетуванням) та вивченням медичної документації. Для забезпечення об'єктивізації висновків дослідження медичної документації відбирали документи методом випадкової вибірки кількістю 20 штук по кожному медичному працівнику, діяльність якого аналізували. Отримані дані за відповідями на анкети наведено в таблиці 1 та проілюстровано на рисунку 2.

Як видно, більшість пацієнтів після проведення обстеження задоволена роботою медичного персоналу діагностичного відділення. Варто відмітити, що для підвищення своєї кваліфікації кожен медичний працівник проходить стажування та курси тематичного вдосконалення в Україні та за кордоном. Щомісяця організовують внутрішньоклінічні наради 3

таблиця 1. Відповіді пацієнтів щодо оцінки результатів роботи медичних сестер діагностичного відділення

\begin{tabular}{|c|c|c|c|c|c|}
\hline \multirow{2}{*}{$\begin{array}{c}\text { номер } \\
\text { медсестри }\end{array}$} & $\begin{array}{c}\text { «задоволений } \\
\text { роботою» }\end{array}$ & $\begin{array}{c}\text { «незадоволений } \\
\text { роботою» }\end{array}$ & «мені байдуже» & не взяв участі & $\begin{array}{c}\text { «визначусь } \\
\text { пізніше» }\end{array}$ \\
\hline 1 & 15 & 1 & 2 & 2 & - \\
\hline 2 & 12 & 4 & - & 1 & 1 \\
\hline 3 & 17 & 1 & - & 1 & 1 \\
\hline 4 & 19 & - & - & 1 & - \\
\hline 5 & 11 & 2 & 3 & - & 2 \\
\hline 6 & 16 & 1 & 2 & - & - \\
\hline 7 & 19 & - & 1 & - & - \\
\hline 8 & 16 & 2 & 2 & & \\
\hline
\end{tabular}




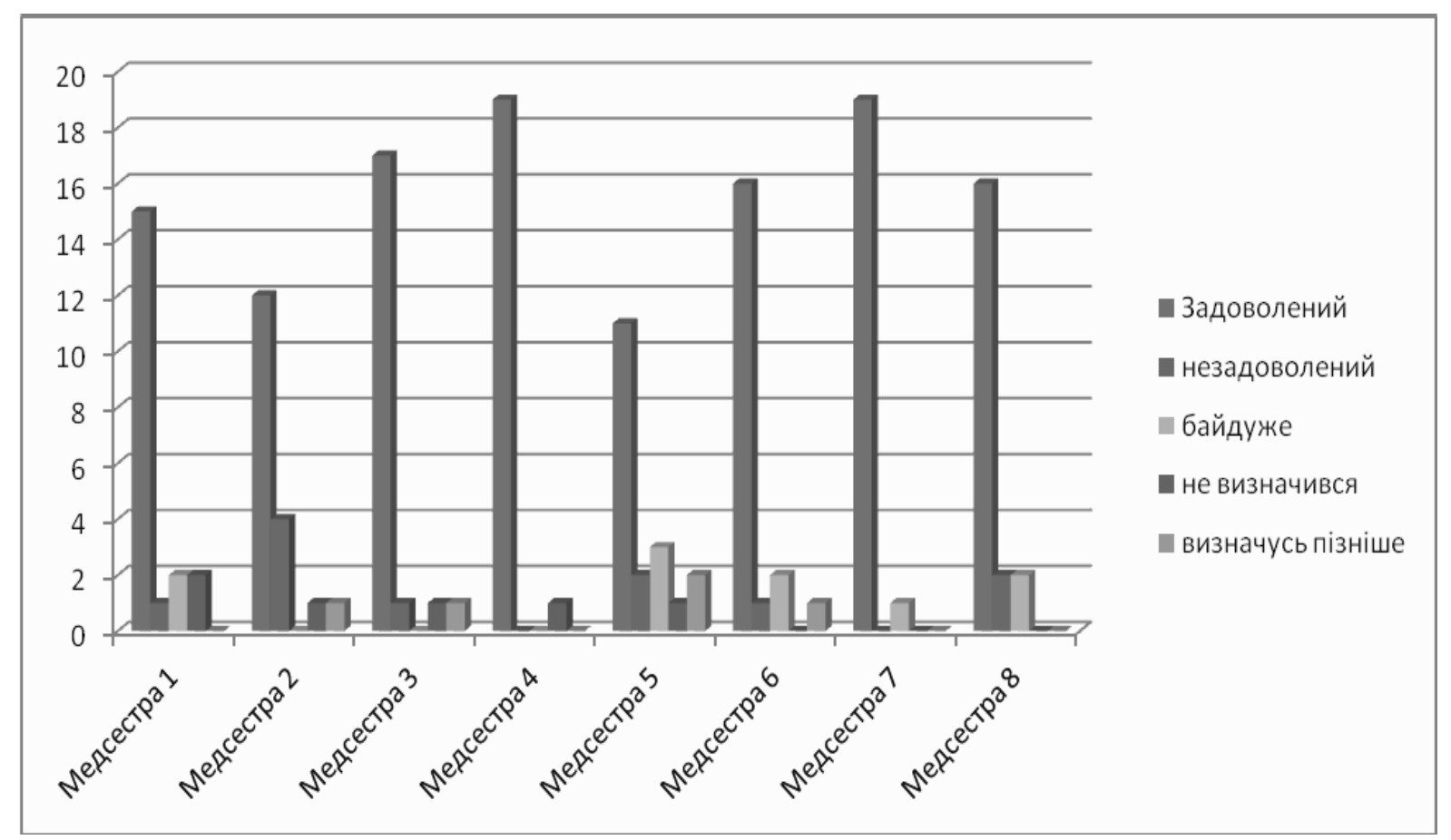

Puc. 2. Відповіді пацієнтів щодо оцінки результатів роботи медичних сестер діагностичного відділення.

планування роботи, аналізу помилок та розробки шляхів покращення діяльності.

Окрім того, оцінивши показники роботи 8 медсестер встановлено, що кращими вони були у медсестер, які мають вищу освіту та більший досвід роботи. Відповідно, нижчі показники у медсестер, які працюють в сфері приватної медичної відносно недавно.

Для оцінки кваліфікації медичних сестер проводилось вивчення точності проведення діагностичних вимірювань, які виконує медична сестра, зокрема вимірювання внутрішньоочного тиску на безконтактному пневмотонометрі Tomeу та лазерної оптичної біометрії на апараті IOL-master, виробництва Carl Zeiss. Контрольні вимірювання параметрів ока проводились лікарем, щоб порівняти отримані результати та оцінити точність виконання процедур. При оцінці правильності вимірювання очного тиску та лазерної біометрії було враховано, що прилад вже під час обстеження аналізує похибку в обстеженні, при цьому враховуються об'єктивні та суб'єктивні причини, що можуть впливати на результат. Під час обробки даних 100 пацієнтів із випадкової вибірки за період з 01.02.16 до 01.03.2016 р. виявлено, що вимірювання очного тиску без похибки, яку фіксує прилад, було здійснено у 78 \% пацієнтів, а з похибкою, відповідно, 22 \% хворих. Варто відмітити, що на цей показник також впливає контакт медсестри з пацієнтом, точність вказівок та рекомендацій, яких потрібно дотримуватись під час вимірювання, та бажання хворої людини виконувати правила.

Проведено контроль теоретичних знань медичних сестер методом тестування, яке проводилось старшою медичною сестрою / заступником головного лікаря з медичної частини в період з січня 2015 до квітня 2016 р. Також було проведено опитування лікарів щодо відповідності дій середнього медичного персоналу до розроблених алгоритмів роботи. Тестування щодо знань та вмінь медичної сестри офтальмологічного кабінету пройшли 97 \% медичного персоналу, з них 77 \% склали його на «відмінно» та 20 \% на «добре».

Висновки. 1. Для забезпечення успішного контролю за якістю сестринської допомоги керівникам сестринських служб необхідно розробити відповідні методи оцінки та системи показників, що ії характеризують.

2. Для забезпечення ефективної роботи середнього медичного персоналу на сучасному рівні необхідне постійне вдосконалення та підвищення рівня практичної підготовки медсестер шляхом стажування в закладах із високим рівнем матеріально-технічного оснащення, опрацювання сучасної медичної літератури, ознайомлення з наказами МОЗ, вивчення сучасних комп'ютерних програм та знання психологічних навичок співпраці з лікарем та пацієнтом.

3. Внаслідок проведеного дослідження на прикладі приватного медичного центру ТОВ «Центр хірургії 
ока професора Загурського» встановлено, що робота медичної сестри розглядається як робота помічника лікаря, що дозволяє оптимізувати час та якість роботи медичного центру та збільшує економічну ефективність, задоволеність пацієнтів та рівень надання медичних послуг.

\section{ЛІТЕРАТУРА}

1. Толстанов О. К. Організація контролю якості медичної допомоги в закладах охорони здоров'я : методичні рекомендації МОЗ від 2013 р.

2. Кузьмінський П. Й. Державне управління системою підготовки медичних сестер в Україні: вступ до проблеми [Електронний ресурс] / П. Й. Кузьмінський // Державне управління: удосконалення та розвиток. - 2012. - № 5. Режим доступу : http//www.dy.nauka.com.ua).

3. Шегедин М. Б. Реформування медсестринської освіти: національний та світовий досвід / М. Б. Шегедин // Педагогіка та психологія професійної освіти. - 1997. - № 2. C. 118-121.
4. Об'єктивна та неупереджена оцінка якості надання медичних послуг середнім медичним персоналом дозволить проаналізувати шляхи вдосконалення навчання медсестер, розробити методи контролю та мотивації персоналу та диференціювати оплату праці працівників із різним освітньо-кваліфікаційним рівнем.

4. Бойко А. Т. Качество медицинской помощи. Проблемы обеспечения / А. Т. Бойко // Мир медицины. - 2001. № 1-2.

5. Мартиненко Л .В. Якість медичної допомоги пацієнту - якість життя медика / Л. В. Мартиненко // Жіночий лікар. - 2006. - № 1. - С. 36.

6. Краснокутський Н. С. Потенціал підприємства: формування та оцінка : навч. посіб. / Н. С. Краснокутський. - К. : Центр навчальної літератури, 2005. - 352 с.

7. Сабадишин Р. Процес реформування медколеджів в інститути сестринської освіти має бути поступовим [Електронний ресурс] / Р. Сабадишин // Медичний вісник 2008. - Режим доступу : medvisnyk.org.ua.

Отримано 03.11.16 